\title{
Article \\ Thermodynamic Assessment of Ti-Al-Fe-V Quaternary System Applied to Novel Titanium Alloys Designing
}

\author{
Qisheng Feng ${ }^{1}$, Baohua Duan ${ }^{1}$, Lu Mao ${ }^{1}$, Lina Jiao ${ }^{1}$, Guangyao Chen ${ }^{1,2, *}$, Xionggang Lu ${ }^{1,2,3}$ (D) \\ and Chonghe $\mathrm{Li}^{1,2, *}$
}

check for updates

Citation: Feng, Q.; Duan, B.; Mao, L.; Jiao, L.; Chen, G.; Lu, X.; Li, C. Thermodynamic Assessment of Ti-Al-Fe-V Quaternary System Applied to Novel Titanium Alloys Designing. Metals 2022, 12, 444. https://doi.org/10.3390/ met12030444

Academic Editor: Martin Bache

Received: 8 February 2022

Accepted: 2 March 2022

Published: 4 March 2022

Publisher's Note: MDPI stays neutral with regard to jurisdictional claims in published maps and institutional affiliations.

Copyright: (C) 2022 by the authors. Licensee MDPI, Basel, Switzerland. This article is an open access article distributed under the terms and conditions of the Creative Commons Attribution (CC BY) license (https:// creativecommons.org/licenses/by/ $4.0 /)$.
1 State Key Laboratory of Advanced Special Steel, Shanghai Key Laboratory of Advanced Ferrometallurgy, School of Materials Science and Engineering, Shanghai University, Shanghai 200072, China; fengqisheng@shu.edu.cn (Q.F.); duanbaohua@shu.edu.cn (B.D.); maolu@shu.edu.cn (L.M.); linda2018@shu.edu.cn (L.J.); luxg@shu.edu.cn (X.L.)

2 Shanghai Special Casting Engineering Technology Research Center, Shanghai 201605, China

3 College of Materials, Shanghai DianJi University, Shanghai 201306, China

* Correspondence: cgybless1@shu.edu.cn (G.C.); chli@staff.shu.edu.cn (C.L.); Tel./Fax: +86-021-5633-2934 (C.L.)

\begin{abstract}
The Ti-Al-Fe-V quaternary system is a very useful system for titanium alloy development. However, there are few reports on the thermodynamic description of this system. In the present work, the experimental investigation and thermodynamic description of the relative sub-systems of the Ti-Al-Fe-V quaternary system are summarized and reviewed, wherein the Ti-Fe-V system is re-assessed by using CALPHAD (CALculation of PHAse Diagrams) approach. The thermodynamic database of the Ti-Al-Fe-V quaternary system is established by extrapolating the thermodynamic descriptions of all sub- systems. Then, a method of titanium alloy design combining Mo equivalent with CALPHAD is proposed. The pseudo-binary sections with $\mathrm{V}: \mathrm{Fe}=3.5: 1$ and $\mathrm{Al}=0.0,3.0,4.5$ and $6.0 \mathrm{wt} \%$ are calculated. Finally, three different types of titanium alloys are recommended according to the new method.
\end{abstract}

Keywords: Ti-Al-Fe-V system; thermodynamic assessment; CALPHAD; titanium alloys

\section{Introduction}

As important lightweight structural materials, titanium and titanium alloys are widely used in aviation, aerospace, vehicle engineering, biomedical engineering and other fields due to their excellent performance [1-3]. Although titanium elements are abundant in the Earth's crust, in 2016, the world output of titanium sponges was only 183,277 metric tons [4]. The high production cost of titanium alloys limits their development and application. Recently, the low-cost preparation of titanium alloys and the development of low-cost titanium alloys have become the focus of research [5-7]. Therefore, we can reduce the processing cost of titanium alloy by using methods such as short technological process, for example, the use of powder metallurgy and other near net shaping technology, and increasing the yield by optimizing the heating temperature, deformation and distortion temperature. The cost of the related processing accounts for $60 \%$ of the total cost of commercial titanium alloys, while the raw materials account for $40 \%$ [8]. On the other hand, we can use inexpensive raw materials (alloying elements) to design titanium alloys. Specifically, scholars have tried to replace expensive isomorphic $\beta$-type elements such as $\mathrm{V}, \mathrm{Mo}$ and $\mathrm{Nb}$ with inexpensive eutectoid $\beta$-type elements such as $\mathrm{Fe}, \mathrm{Cr}$ and $\mathrm{Mn}$, which has proven to be an effective way to reduce the cost of titanium alloys [9]. ATI company has developed ATI 425 low-cost titanium alloy using inexpensive Fe instead of part V [10], which not only reduces the cost, but also reduces the possibility of the occurrence of brittle phase, thus this alloy keeps the good mechanical properties and can be applied to military armor materials. It is important to thoroughly understand the 
thermodynamics of alloys to improve their properties [11]. Therefore, it is essential to thermodynamic assessment of the Ti-Al-Fe-V quaternary system for developing novel titanium alloys containing these elements.

In this work, the thermodynamic evaluation of six sub-binary systems (Ti-Al, Ti-Fe, Ti-V, Al-Fe, Al-V and Fe-V) and four sub-ternary systems (Ti-Al-Fe, Ti-Al-V, Ti-Fe-V and Al$\mathrm{Fe}-\mathrm{V}$ ) were reviewed, and the thermodynamic re-evaluation of Ti-Fe-V system was carried out, and the construction of the thermodynamic database of the Ti-Al-Fe-V quaternary system was directly extrapolated from four sub-ternary systems. Then, a method of combining Mo equivalent with CALPHAD was proposed to design novel titanium alloys. Finally, pseudo-binary sections were calculated with the $\mathrm{V}: \mathrm{Fe}=3.5: 1$ and $\mathrm{Al}=0.0,3.0,4.5$ and $6.0 \mathrm{wt} \%$, and three novel titanium alloys were designed.

\section{Literature Review}

\subsection{Binary Systems}

The Ti-Al system was optimized by many researchers [12-18], which included liquid, $\alpha(\mathrm{Ti}), \beta, \beta_{0}, \alpha(\mathrm{Al}), \mathrm{Ti}_{3} \mathrm{Al}, \mathrm{TiAl}, \mathrm{Ti}_{3} \mathrm{Al}_{5}, \mathrm{Ti}_{2} \mathrm{Al}_{5}, \mathrm{TiAl}_{2}$, the high-temperature phase $\mathrm{H}_{-} \mathrm{TiAl}_{3}$ and the low-temperature phase $\mathrm{L}_{-} \mathrm{TiAl}_{3}$. The thermodynamic parameters of this system used in the present work are from Witusiewicz et al. [18] and the calculated Ti-Al phase diagram is shown in Figure 1. For the Ti-Fe system, several thermodynamic descriptions are available [19-24], in which liquid, $\gamma(\mathrm{Fe}), \beta, \alpha(\mathrm{Ti})$, TiFe and Fe 2 Ti were included. Bo's [24] work is accepted in the present work and the calculated Ti-Fe phase diagram is shown in Figure 2. The Ti-V system was optimized by [25-27], and three phases of liquid, $\beta$ and $\alpha(\mathrm{Ti})$ were included. The calculated $\mathrm{Ti}-\mathrm{V}$ phase diagram using the thermodynamic parameters from Ghosh et al. [27] is shown in Figure 3. The Al-Fe system has been reported by many researchers [28-30] and includes liquid, $\beta, \beta_{0}, \gamma(\mathrm{Fe}), \alpha(\mathrm{Al}), \mathrm{Al}_{8} \mathrm{Fe}_{5}, \mathrm{Al}_{2} \mathrm{Fe}, \mathrm{Al}_{5} \mathrm{Fe}_{2}$ and $\mathrm{Al}_{13} \mathrm{Fe}_{4}$. Sundman's [30] thermodynamic parameters are adopted in the present work and the calculated Al-Fe phase diagram is shown in Figure 4. Several thermodynamic parameters of the Al-V system are available [31,32], in which liquid, $\alpha(\mathrm{Al}), \beta, \mathrm{Al}_{21} \mathrm{~V}_{2}$, $\mathrm{Al}_{45} \mathrm{~V}_{7}, \mathrm{Al}_{23} \mathrm{~V}_{4}, \mathrm{Al}_{3} \mathrm{~V}$ and $\mathrm{Al}_{8} \mathrm{~V}_{5}$ are included. The thermodynamic parameters used in the present work are from Gong et al. [32] and the calculated Al-V phase diagram is shown in Figure 5. The Fe-V system was optimized by [33-35], and four phases of liquid, $\gamma(\mathrm{Fe}), \beta$ and sigma were included. The thermodynamic parameters are accepted in the present work from Kumar et al. [35] and the calculated Fe-V phase diagram is shown in Figure 6. For the evaluation of the six binary systems mentioned above, only those that are most consistent with experimental data will be accepted in the present work. The crystallographic data of individual phases in the six binary systems $[18,24,27,30,32,35]$ are listed in Table 1.

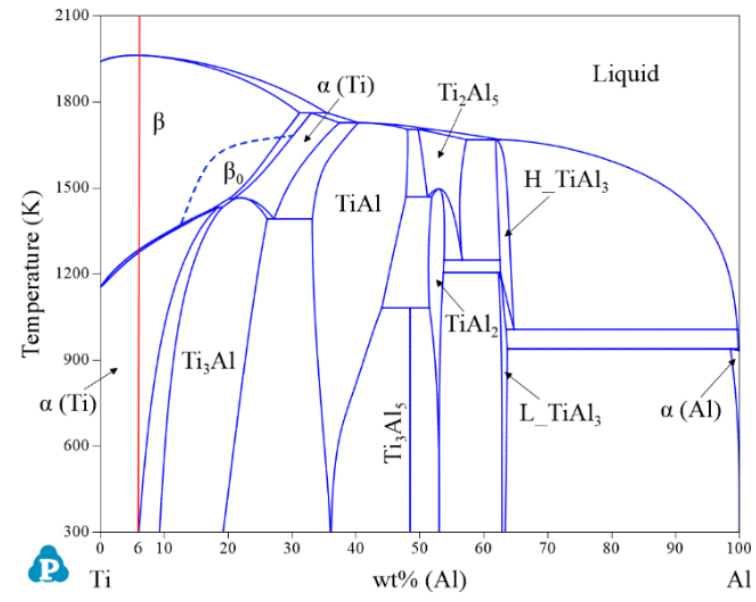

Figure 1. Calculated Ti-Al phase diagram using the thermodynamic parameters obtained by Witusiewicz et al. [18]. 


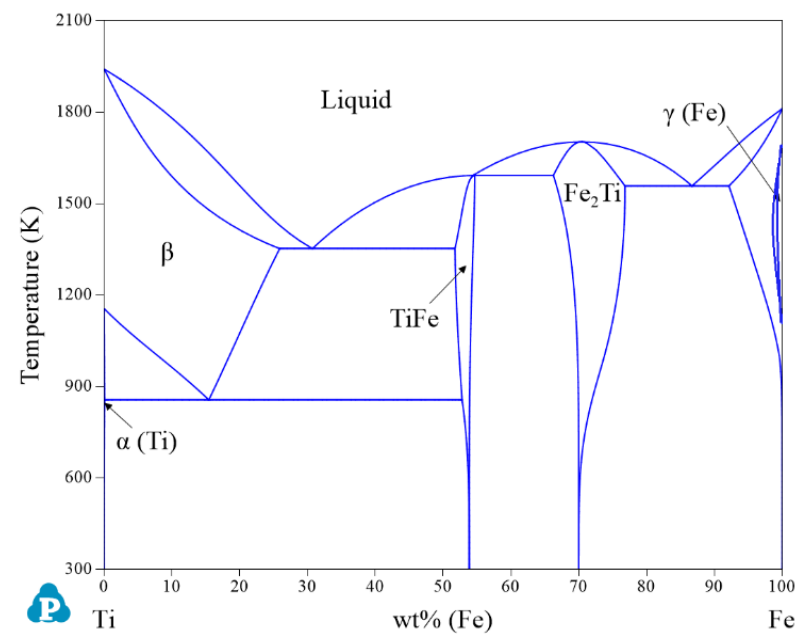

Figure 2. Calculated Ti-Fe phase diagram using the thermodynamic parameters obtained by Bo et al. [24].

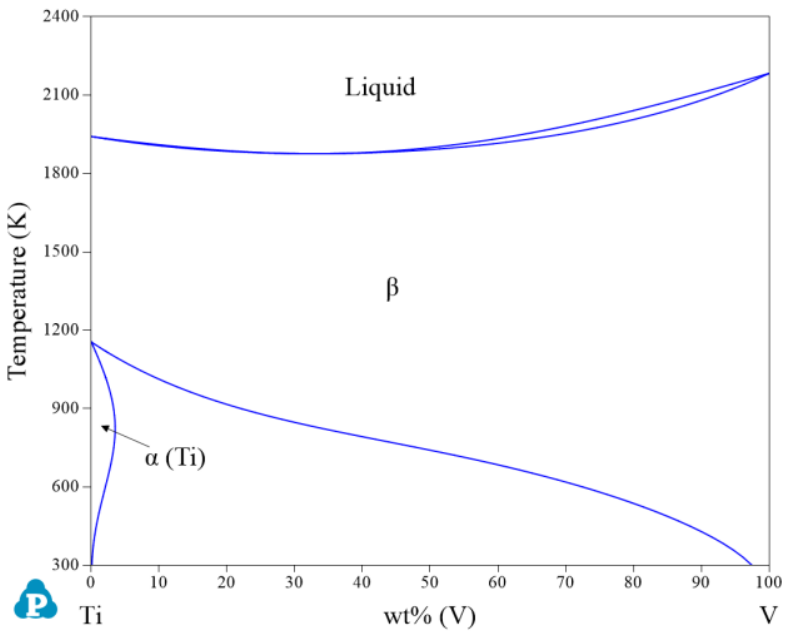

Figure 3. Calculated Ti-V phase diagram using the thermodynamic parameters obtained by Ghosh et al. [27].

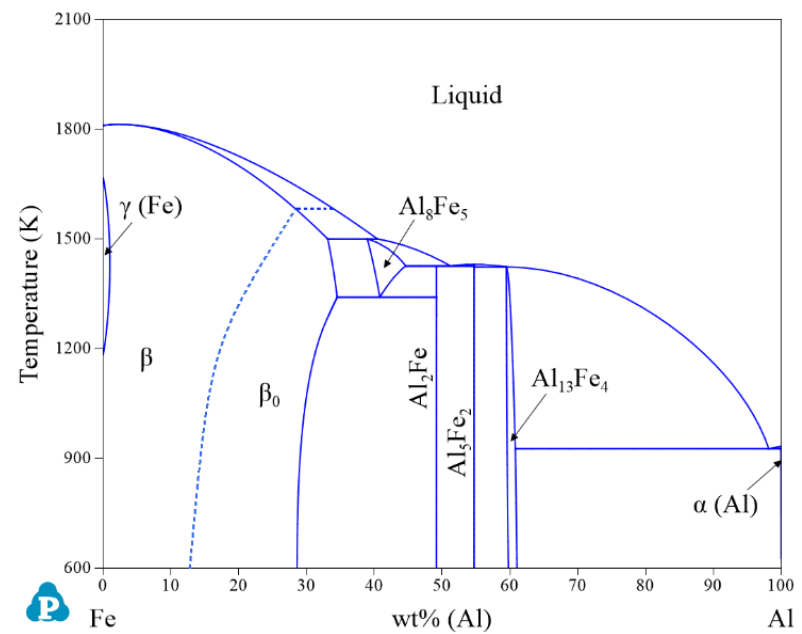

Figure 4. Calculated Fe-Al phase diagram using the thermodynamic parameters obtained by Sundman et al. [30]. 


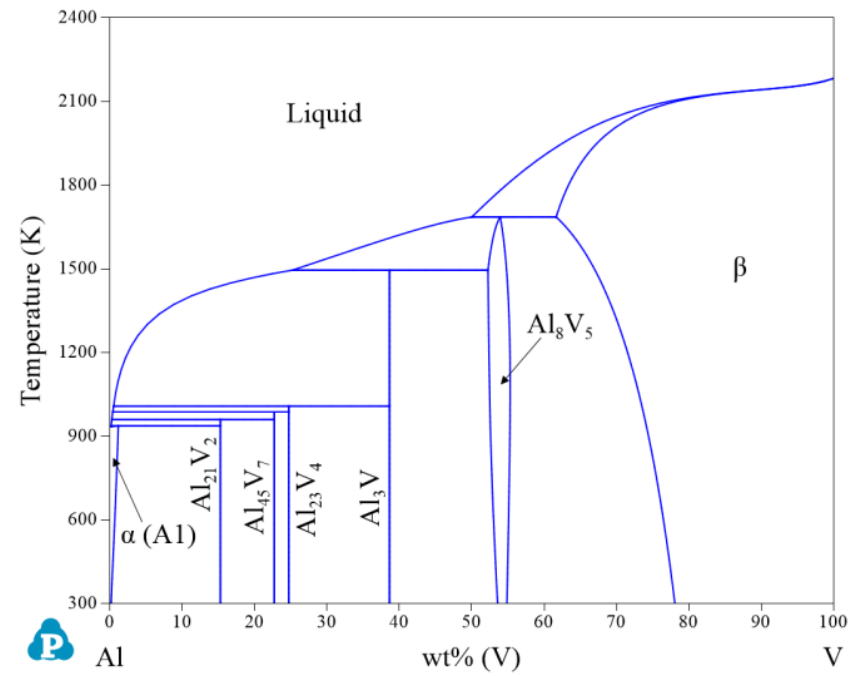

Figure 5. Calculated Al-V phase diagram using the thermodynamic parameters obtained by Gong et al. [32].

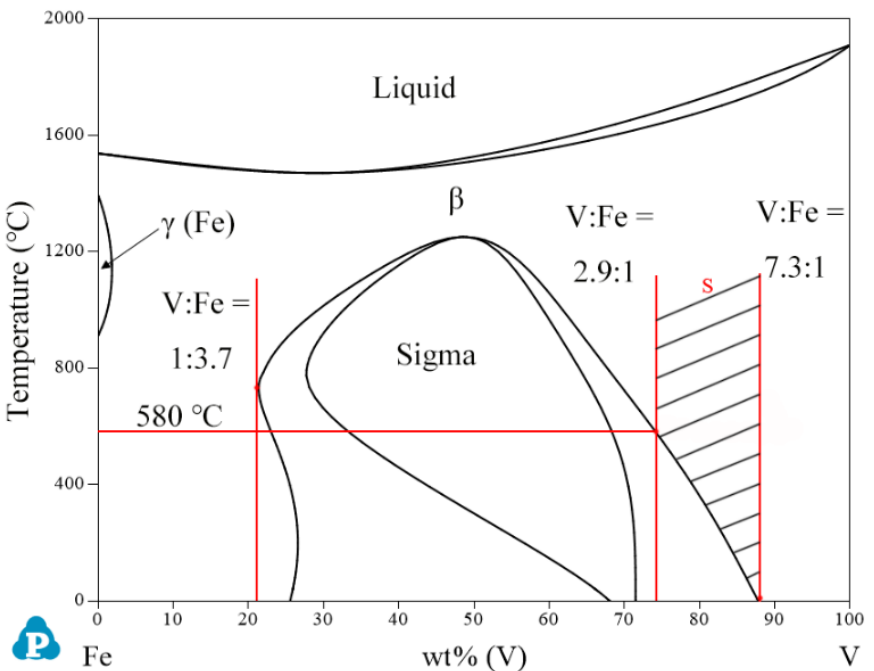

Figure 6. Calculated $\mathrm{Fe}-\mathrm{V}$ phase diagram using the thermodynamic parameters obtained by Kumar et al. [35].

Table 1. Crystallographic data of individual phases in the six binary systems.

\begin{tabular}{|c|c|c|c|c|c|c|}
\hline System & Phase & $\begin{array}{l}\text { Struktur- } \\
\text { Bericht }\end{array}$ & Prototype & $\begin{array}{l}\text { Person } \\
\text { Symbol }\end{array}$ & $\begin{array}{l}\text { Space } \\
\text { Group }\end{array}$ & References \\
\hline \multirow[t]{11}{*}{ Ti-Al } & $\alpha(\mathrm{Al})$ & FCC_A1 & $\mathrm{Cu}$ & $\mathrm{cF} 4$ & $\mathrm{Fm} \overline{3} \mathrm{~m}$ & [18] \\
\hline & $\beta$ & BCC_A2 & W & cI2 & $\operatorname{Im} \overline{3} \mathrm{~m}$ & [18] \\
\hline & $\beta_{0}$ & BCC_B2 & $\mathrm{CsCl}$ & cI2 & $\operatorname{Pm} \overline{3} \mathrm{~m}$ & [18] \\
\hline & $\alpha(\mathrm{Ti})$ & HCP_A3 & $\mathrm{Mg}$ & hP2 & $\mathrm{P}_{3} / \mathrm{mmc}$ & [18] \\
\hline & $\mathrm{Ti}_{3} \mathrm{Al}$ & $\mathrm{DO}_{19}$ & $\mathrm{Ni}_{3} \mathrm{Sn}$ & hP8 & $\mathrm{P}_{3} / \mathrm{mmc}$ & [18] \\
\hline & TiAl & $\mathrm{L} 1_{0}$ & $\mathrm{AuCu}$ & $\mathrm{tP} 4$ & $\mathrm{P} 4 / \mathrm{mmm}$ & [18] \\
\hline & $\mathrm{Ti}_{3} \mathrm{Al}_{5}$ & - & $\mathrm{Ti}_{3} \mathrm{Al}_{5}$ & tP32 & $\mathrm{P} 4 / \mathrm{mbm}$ & [18] \\
\hline & $\mathrm{Ti}_{2} \mathrm{Al}_{5}$ & - & $\mathrm{Ti}_{2} \mathrm{Al}_{5}$ & tP28 & $\mathrm{P} 4 / \mathrm{mmm}$ & [18] \\
\hline & $\mathrm{TiAl}_{2}$ & - & $\mathrm{HfGa}_{2}$ & $\mathrm{tI} 24$ & $\mathrm{I}_{1} / \mathrm{amd}$ & [18] \\
\hline & $\mathrm{H}_{-} \mathrm{TiAl}_{3}$ & $\mathrm{DO}_{22}$ & $\mathrm{TiAl}_{3}(\mathrm{~h})$ & $\mathrm{tI} 8$ & $\mathrm{I} 4 / \mathrm{mmm}$ & [18] \\
\hline & $\mathrm{L}_{-} \mathrm{TiAl}_{3}$ & - & $\mathrm{TiAl}_{3}(\mathrm{l})$ & tI32 & $\mathrm{I} 4 / \mathrm{mmm}$ & [18] \\
\hline
\end{tabular}


Table 1. Cont.

\begin{tabular}{|c|c|c|c|c|c|c|}
\hline System & Phase & $\begin{array}{l}\text { Struktur- } \\
\text { Bericht }\end{array}$ & Prototype & $\begin{array}{l}\text { Person } \\
\text { Symbol }\end{array}$ & $\begin{array}{l}\text { Space } \\
\text { Group }\end{array}$ & References \\
\hline \multirow[t]{5}{*}{ Ti-Fe } & $\gamma(\mathrm{Fe})$ & FCC_A1 & $\mathrm{Cu}$ & $\mathrm{cF} 4$ & $\mathrm{Fm} \overline{3} \mathrm{~m}$ & [36] \\
\hline & $\beta$ & BCC_A2 & W & cI2 & $\operatorname{Im} \overline{3} \mathrm{~m}$ & [36] \\
\hline & $\alpha(\mathrm{Ti})$ & HCP_A3 & $\mathrm{Mg}$ & hP2 & $\mathrm{P}_{3} / \mathrm{mmc}$ & [36] \\
\hline & TiFe & BCC_B2 & $\mathrm{CsCl}$ & $\mathrm{cP} 2$ & $\operatorname{Pm} \overline{3} \mathrm{~m}$ & [36] \\
\hline & $\mathrm{Fe}_{2} \mathrm{Ti}$ & $\mathrm{C} 14$ & $\mathrm{MgZn} 2$ & hP12 & $\mathrm{P}_{3} / \mathrm{mmc}$ & [36] \\
\hline \multirow[t]{2}{*}{ Ti-V } & $\beta$ & BCC_A2 & W & cI2 & $\operatorname{Im} \overline{3} \mathrm{~m}$ & [27] \\
\hline & $\alpha(\mathrm{Ti})$ & HCP_A3 & $\mathrm{Mg}$ & hP2 & $\mathrm{P}_{3} / \mathrm{mmc}$ & [27] \\
\hline \multirow{7}{*}{$\mathrm{Fe}-\mathrm{Al}$} & $\gamma(\mathrm{Fe})$ and $\alpha(\mathrm{Al})$ & FCC_A1 & $\mathrm{Cu}$ & $\mathrm{cF} 4$ & $\mathrm{Fm} \overline{3} \mathrm{~m}$ & [30] \\
\hline & $\beta$ & BCC_A2 & W & $\mathrm{cI} 2$ & $\operatorname{Im} \overline{3} \mathrm{~m}$ & [30] \\
\hline & $\beta_{0}$ & BCC_B2 & $\mathrm{CsCl}$ & $\mathrm{cP} 8$ & $\operatorname{Pm} \overline{3} \mathrm{~m}$ & [30] \\
\hline & $\mathrm{Al}_{8} \mathrm{Fe}_{5}$ & $\mathrm{D} 8_{2}$ & $\mathrm{Cu}_{5} \mathrm{Zn}_{8}$ & cI52 & $\mathrm{I} 4 \overline{3} \mathrm{~m}$ & [30] \\
\hline & $\mathrm{Al}_{2} \mathrm{Fe}$ & - & $\mathrm{Al}_{2} \mathrm{Fe}$ & aP18 & P1 & [30] \\
\hline & $\mathrm{Al}_{5} \mathrm{Fe}_{2}$ & - & - & $\mathrm{oC} ?$ & $\mathrm{Cmcm}$ & [30] \\
\hline & $\mathrm{Al}_{13} \mathrm{Fe}_{4}$ & - & - & $\mathrm{mC102}$ & $\mathrm{C} 2 / \mathrm{m}$ & [30] \\
\hline \multirow[t]{7}{*}{ Al-V } & $\alpha(\mathrm{Al})$ & FCC_A1 & $\mathrm{Cu}$ & $\mathrm{cF} 4$ & $\mathrm{Fm} \overline{3} \mathrm{~m}$ & [37] \\
\hline & $\beta$ & BCC_A2 & W & cI2 & $\operatorname{Im} \overline{3} \mathrm{~m}$ & [37] \\
\hline & $\mathrm{Al}_{21} \mathrm{~V}_{2}$ & - & $\mathrm{Al}_{21} \mathrm{~V}_{2}$ & cF176 & $\mathrm{Fd} \overline{3} \mathrm{~m}$ & [37] \\
\hline & $\mathrm{Al}_{45} \mathrm{~V}_{7}$ & - & $\mathrm{Al}_{45} \mathrm{~V}_{7}$ & $\mathrm{mC104}$ & $\mathrm{C} 2 / \mathrm{m}$ & [37] \\
\hline & $\mathrm{Al}_{23} \mathrm{~V}_{4}$ & - & $\mathrm{Al}_{23} \mathrm{~V}_{4}$ & hP54 & $\mathrm{P}_{3} / \mathrm{mmc}$ & [37] \\
\hline & $\mathrm{Al}_{3} \mathrm{~V}$ & - & $\mathrm{Al}_{3} \mathrm{Ti}$ & tI8 & $\mathrm{I} 4 / \mathrm{mmm}$ & [37] \\
\hline & $\mathrm{Al}_{8} \mathrm{~V}_{5}$ & - & $\mathrm{Cu}_{5} \mathrm{Zn}_{8}$ & cI52 & $\mathrm{I} \overline{4} 3 \mathrm{~m}$ & [37] \\
\hline \multirow[t]{3}{*}{$\mathrm{Fe}-\mathrm{V}$} & $\gamma(\mathrm{Fe})$ & FCC_A1 & $\mathrm{Cu}$ & $\mathrm{cF} 4$ & $\mathrm{Fm} \overline{3} \mathrm{~m}$ & [38] \\
\hline & $\beta$ & BCC_A2 & W & $\mathrm{cI} 2$ & $\operatorname{Im} \overline{3} \mathrm{~m}$ & [38] \\
\hline & sigma & $\mathrm{D} \overline{\mathrm{b}}_{\mathrm{b}}$ & $\sigma \mathrm{CrFe}$ & tP30 & - & [38] \\
\hline
\end{tabular}

\subsection{Ternary Systems}

Since Ti-Al-Fe based alloys are widely used, the Ti-Al-Fe system has been very well investigated [39-46]. The thermodynamic parameters are accepted in this study from $\mathrm{Hu}$ et al. [46]. The Ti-Al-V ternary system was first evaluated by Hayes et al. [47] and reproduces experimental data from Farrar et al. [48]. Isothermal sections of $873 \mathrm{~K}$ to $1473 \mathrm{~K}$ were established by Ahmed et al. [49], and it was reported that at $1473 \mathrm{~K}$ or above, the assumed one-phase $(\mathrm{Ti}, \mathrm{V})_{1} \mathrm{Al}_{3}$ can be divided into two different phases. A new phase named $\mathrm{H}_{2}$ in the alloys $\mathrm{Al}_{55} \mathrm{Ti}_{10} \mathrm{~V}_{35}$ and $\mathrm{Al}_{62} \mathrm{Ti}_{10} \mathrm{~V}_{28}$ was detected by Shao et al. [50,51] and Chang et al. [52], and the phase relationship at $1373 \mathrm{~K}$ was determined by Zhang et al. [53]. The thermodynamic re-assessment of this system was carried out based on the above experimental data by Kostov et al. [54], Wang et al. [55] and Lu et al. [56], and the thermodynamic parameters are accepted in this work by Lu et al. [56]. The Al-Fe-V system was studied by [57-61]. The Fe-rich angle phase diagram at $773 \mathrm{~K}$ was reported by Zhao et al. [59]. Subsequently, the Fe-rich isothermal sections at $923 \mathrm{~K}, 973 \mathrm{~K}$ and $1023 \mathrm{~K}$ were experimentally determined by Maebashi [60]. The latest thermodynamic description of this system was re-evaluated by Wang et al. [61], which was in good agreement with the above experimental data. Therefore, her work is accepted in the present work. The experimental data of the Ti-Fe-V system on the basis of previous work [62,63] were reviewed by Villars et al. [64] and recommended three isothermal sections at $300 \mathrm{~K}, 1073 \mathrm{~K}$ and $1273 \mathrm{~K}$, two vertical sections at the FeTi-V and the $\mathrm{Fe}_{2} \mathrm{Ti}-\mathrm{V}$ joins and liquidus surface projection. Prima et al. [65] determined the homogeneity of $\mathrm{V}$ in the $\mathrm{Fe}_{2} \mathrm{Ti}$ phase. Later, isothermal sections at $1273 \mathrm{~K}$ and $1473 \mathrm{~K}$ were confirmed by Massicot et al. [66], and a tentative liquidus surface projection with a quasi-peritectic reaction liquid $+\mathrm{Fe}_{2} \mathrm{Ti} \rightarrow \mathrm{bcc}+\mathrm{FeTi}$ at $1413 \mathrm{~K}$ was presented. Recently, the thermodynamic description of the Ti-Fe-V system was assessed by Guo et al. [67], where the model of the sigma phase is described as $(\mathrm{Fe}, \mathrm{Ti}, \mathrm{V})_{10}(\mathrm{Fe}, \mathrm{Ti}, \mathrm{V})_{20}$. We know that the three binary systems used in Guo's work are Ti-V [25], Ti-Fe [23] and Fe-V [35], and the models of some phases of the latter two systems are modified. However, the literature review in Section 2.1 shows that the best evaluation of the three binary systems is the work 
of Ghosh et al. [27], Bo et al. [24] and Kumar et al. [35]. At the same time, to ensure the consistency of thermodynamic parameters in the present work, the thermodynamic parameters of the Ti-Fe-V system are re-optimized, and the binary systems used are Ti-V [27], Ti-Fe [24] and Fe-V [35], where the model of the sigma phase is defined as $(\mathrm{Fe})_{8}(\mathrm{~V})_{4}(\mathrm{Fe}$, $\mathrm{Ti}, \mathrm{V})_{18}$.

\section{Thermodynamic Modeling}

\subsection{Pure Elements}

In the present work, the Gibbs energy function of each pure element is extracted from the SGTE (Scientific Group Thermodata Europe) compilation by Dinsdale et al. [68]. The Gibbs energy function of element $i(i=\mathrm{Ti}, \mathrm{Al}, \mathrm{Fe}$ and $\mathrm{V})$ is described by the following equation:

$$
{ }^{o} G_{i}^{\phi}(T)=G_{i}^{\phi}(T)-H_{i}^{S E R}=a+b T+c T \ln T+d T^{2}+\frac{e}{T}+\ldots
$$

\subsection{Solution Phases}

In the Ti-Al-Fe-V quaternary system, solution phases liquid, FCC_A1, BCC_A2 and HCP_A3 are included, which are all described with the substitutional solution model. Their Gibbs energies are described by the following expression:

$$
G^{O}=\sum_{i=1}^{n} x_{i}^{0} G_{i}^{O}+R T \sum_{i=1}^{n} x_{i} \ln \left(x_{i}\right)+{ }^{E} G^{O}
$$

where $x_{i}$ is the mole fraction of the pure element $i(i=\mathrm{Ti}, \mathrm{Al}, \mathrm{Fe}$ and $\mathrm{V}),{ }^{0} \mathrm{G}_{i}^{O}$ is the Gibbs energy of the pure component $i, n$ is equal to the number of elements in this system, $R$ is the gas constant and $T$ is the absolute temperature. ${ }^{E} G^{O}$ is the excess Gibbs energy, expressed by the Redlich-Kister polynomial [69]:

$$
{ }^{E} G^{O}=\sum_{i, j=1(i \neq j)}^{n} x_{i} x_{j} \sum_{k=0}^{m} L_{(i, j)}^{k}\left(x_{i}-x_{j}\right)^{k}+\sum_{i, j, l=1(i \neq j \neq l)}^{n} x_{i} x_{j} x_{l} \sum_{k=i, j, l} L_{k} V_{k}
$$

where $L_{(i, j)}^{k}$ is the binary interaction parameters between elements $i$ and $j, L_{k}$ is the ternary interaction parameters. The item $V_{k}$ is defined as:

$$
V_{k}=x_{k}+\left(1-\sum_{p=i, j . l} x_{p}\right) / n
$$

\subsection{Intermetallic Compounds}

In addition to the solution phases, other different types of intermetallic compounds are also included in the Ti-Al-Fe-V quaternary system. In the present work, different and appropriate sublattice models are used for different intermetallic compounds. The general expression of Gibbs energy of sublattice model is as follows:

$$
G^{O}={ }^{r e f} G^{O}+{ }^{i d} G^{O}+{ }^{E} G^{O}
$$

where ${ }^{r e f} G^{O}$ is expressed in terms of compound energy and their associated sublattice species concentrations, $y_{p}^{i}$ :

$$
{ }^{r e f} G^{O}=\sum y_{p}^{i} y_{q}^{j} \ldots y_{s}^{j} G_{(p: q: \ldots: s)}^{0}
$$

where ${ }^{i d} G^{O}$ is the ideal mixing term, which assumes the random mixing of species on each sublattice:

$$
{ }^{i d} G^{O}=R T \sum_{i=1}^{l} n_{i} \sum_{p=1}^{m} y_{p}^{i} \operatorname{In}\left(y_{p}^{i}\right)
$$


where ${ }^{E} G^{O}$ is the excess Gibbs energy, $L$ is the interaction parameter between different species in the same sublattice:

$$
\begin{gathered}
{ }_{G^{O}}{ }=\sum y_{p}^{i} y_{q}^{i} y_{r}^{j} L_{(p: q: r)} \\
L_{(p: q: r)}=\sum_{v} L_{(p: q: r)}^{v}\left(y_{p}^{i}-y_{q}^{j}\right)^{v}
\end{gathered}
$$

\section{Thermodynamic Optimization}

The evaluations of all model parameters were carried out by recurrent runs of the Pan-optimizer module of Pandat software [70], which works by minimizing the square sum of the differences between experimental and computed values. Each piece of experimental information was given a certain weight, and the weight was varied systematically during the optimization process until most of the experimental data were accounted for within the estimated uncertainty limits. The step-by-step optimization method reported by Wang et al. [71] was used in the present work.

\subsection{Ti-Fe-V System}

Through the analysis in Section 2.2, combining the Ti-Fe system [24], Ti-V system [27] and Fe- $\mathrm{V}$ system [35], the Ti-Fe- $\mathrm{V}$ system is re-evaluated. The sigma phase is re-modeled as $(\mathrm{Fe})_{8}(\mathrm{~V})_{4}(\mathrm{Fe}, \mathrm{Ti}, \mathrm{V})_{18}$, and the models of other phases refer to Guo's [67] work to match the thermodynamic parameters of other systems in the present work. The experimental results reported by Massicot et al. [66] are used to reoptimize. The calculated isothermal sections at $1273 \mathrm{~K}$ and $1473 \mathrm{~K}$ in comparison with experimental data [66] are shown in Figure 7, and it is shown that the calculated results are in good agreement with the corresponding experimental data within the error. Figure 8 shows the calculated liquidus surface projection of the Ti-Fe-V system using the thermodynamic parameters of the present work. The thermodynamic parameters of the Fe-Ti-V system obtained in the present work are shown in Table 2.

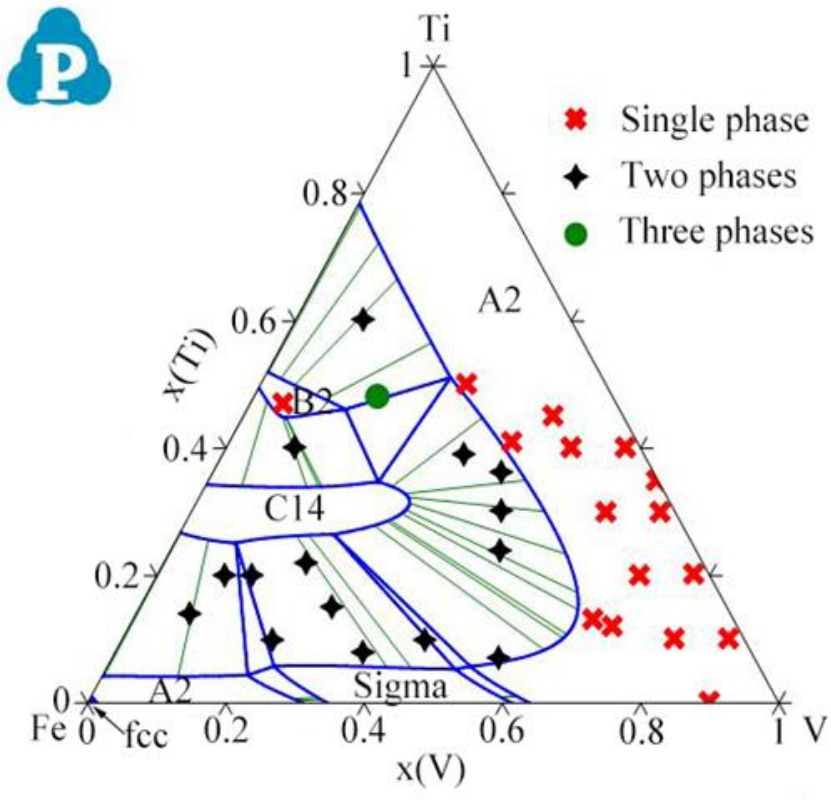

(a)

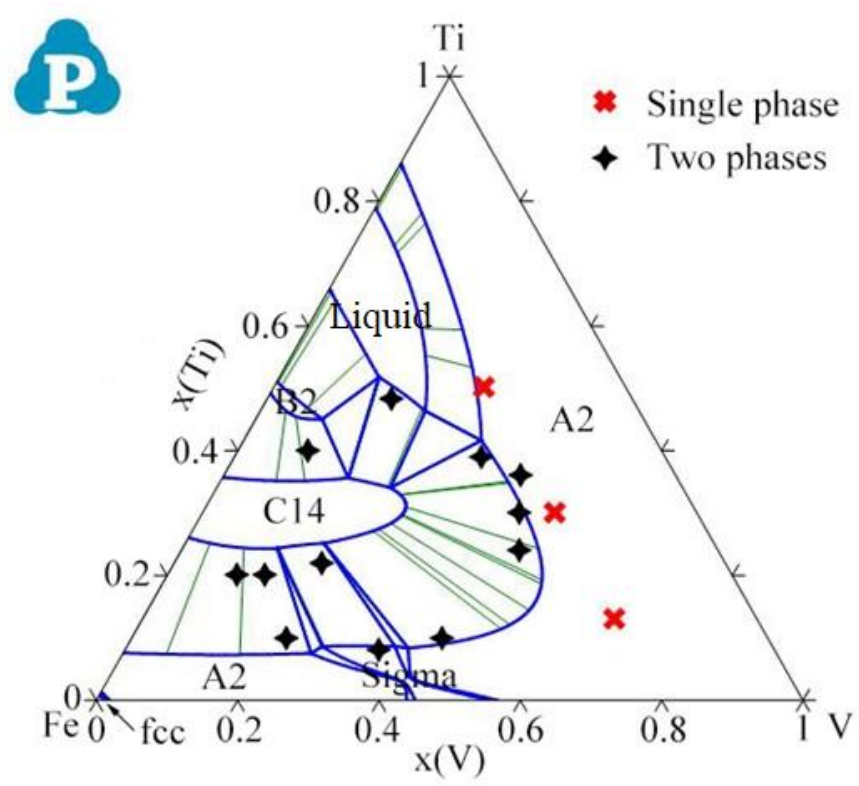

(b)

Figure 7. Calculated isothermal sections at (a) $1273 \mathrm{~K}$ and (b) $1473 \mathrm{~K}$ in the Ti-Fe-V system in comparison with experimental data [66]. 


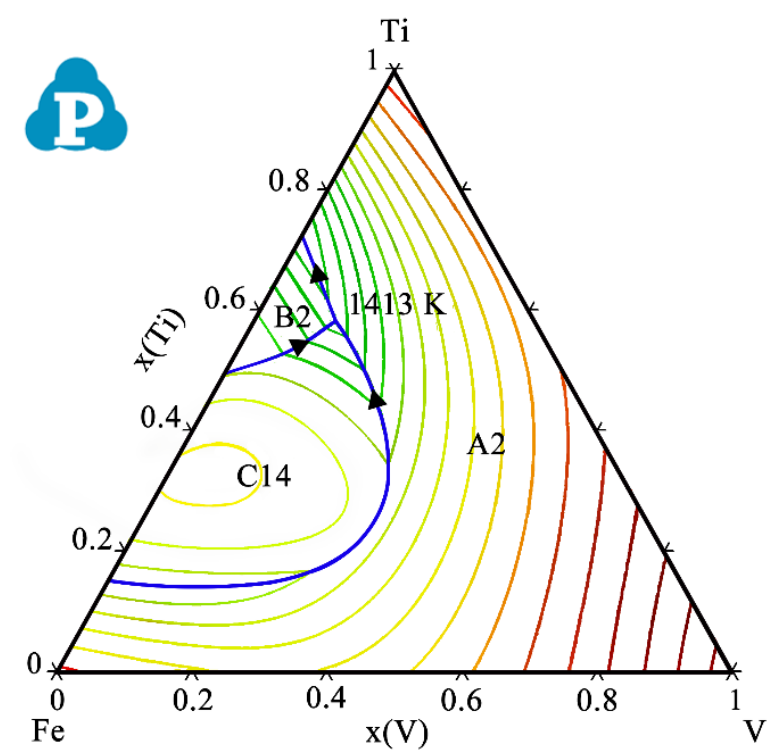

Figure 8. Calculated liquidus surface projection of the Ti-Fe-V system using the present thermodynamic description.

Table 2. Summary of the thermodynamic parameters in the Ti-Fe-V system.

\begin{tabular}{|c|c|c|}
\hline Phase/Model & Thermodynamic Parameters & References \\
\hline $\begin{array}{c}\text { Liquid } \\
(\mathrm{Fe}, \mathrm{Ti}, \mathrm{V})_{1}\end{array}$ & 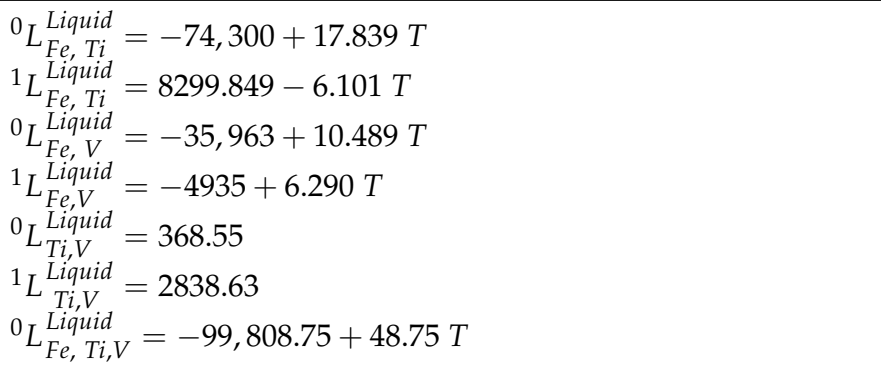 & $\begin{array}{c}\text { [24] } \\
{[24]} \\
{[35]} \\
{[35]} \\
{[27]} \\
{[27]} \\
\text { This work }\end{array}$ \\
\hline $\begin{array}{c}\text { FCC_A1 } \\
(\mathrm{Fe}, \mathrm{Ti}, \mathrm{V})_{1}\end{array}$ & 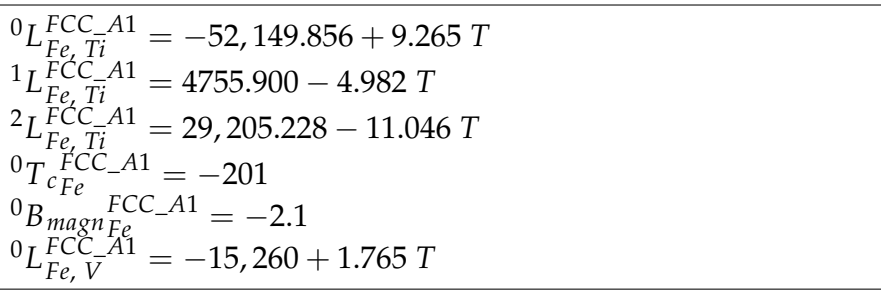 & $\begin{array}{l}{[24]} \\
{[24]} \\
{[24]} \\
{[24]} \\
{[24]} \\
{[35]}\end{array}$ \\
\hline $\begin{array}{c}\text { BCC_A2 } \\
(\mathrm{Fe}, \mathrm{Ti}, \mathrm{V})_{1}\end{array}$ & 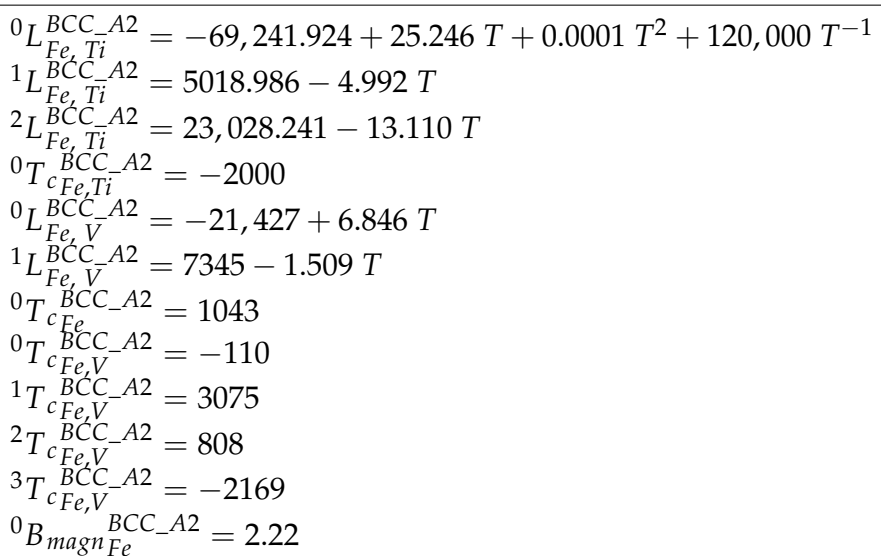 & $\begin{array}{l}{[24]} \\
{[24]} \\
{[24]} \\
{[24]} \\
{[35]} \\
{[35]} \\
{[35]} \\
{[35]} \\
{[35]} \\
{[35]} \\
{[35]} \\
{[35]}\end{array}$ \\
\hline
\end{tabular}


Table 2. Cont.

\begin{tabular}{|c|c|c|}
\hline Phase/Model & Thermodynamic Parameters & References \\
\hline & $\begin{array}{l}{ }^{0} B_{\text {magn }}^{B C C_{-}-} A 2=-2.26 \\
{ }^{0} L_{T i, V}^{B C C_{-} A 2}=6523.17 \\
{ }^{1} L_{T i, V}^{B C C_{-}} A 2=2025.39 \\
{ }^{0} L^{B C} C_{-} A 2=-37,247.5+7.5 T\end{array}$ & $\begin{array}{c}\text { [35] } \\
{[27]} \\
{[27]} \\
\text { This work }\end{array}$ \\
\hline $\begin{array}{l}\text { HCP_A3 } \\
(\mathrm{Fe}, \mathrm{Ti}, \mathrm{V})_{1}\end{array}$ & $\begin{array}{l}{ }^{0} L_{F e, T i}^{H C P} A 3=-25,000+35.004 T \\
{ }^{0} L_{T i, V}^{H C P A}=13,223\end{array}$ & $\begin{array}{l}{[24]} \\
{[27]}\end{array}$ \\
\hline $\begin{array}{c}\text { BCC_B2 } \\
(\mathrm{Fe}, \mathrm{Ti}, \mathrm{V})_{0.5}(\mathrm{Fe}, \mathrm{Ti}, \mathrm{V})_{0.5}\end{array}$ & 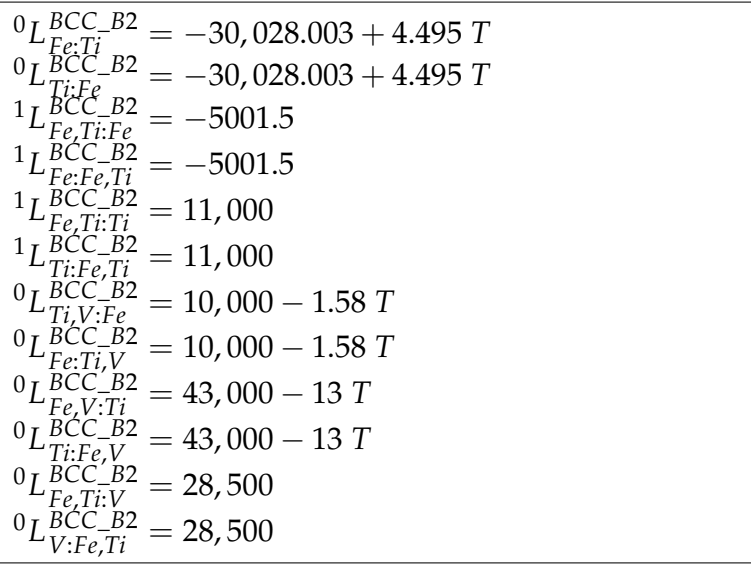 & $\begin{array}{c}\text { [24] } \\
{[24]} \\
{[24]} \\
{[24]} \\
{[24]} \\
{[24]} \\
\text { This work } \\
\text { This work } \\
\text { This work } \\
\text { This work } \\
\text { This work } \\
\text { This work }\end{array}$ \\
\hline $\begin{array}{c}\text { Sigma } \\
(\mathrm{Fe})_{8}(\mathrm{~V})_{4}(\mathrm{Fe}, \mathrm{Ti}, \mathrm{V})_{18}\end{array}$ & 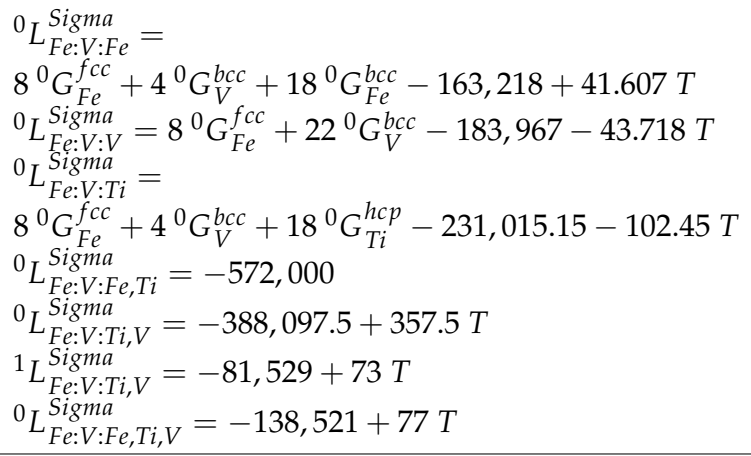 & $\begin{array}{l}\text { [35] } \\
\text { [35] } \\
\text { This work } \\
\text { This work } \\
\text { This work } \\
\text { This work } \\
\text { This work }\end{array}$ \\
\hline $\begin{array}{c}\mathrm{C} 14 \\
(\mathrm{Fe}, \mathrm{Ti}, \mathrm{V})_{2}(\mathrm{Fe}, \mathrm{Ti}, \mathrm{V})_{1}\end{array}$ & $\begin{array}{l}{ }^{0} L_{F e: F e}^{C 14}=3{ }^{0} G_{F e}^{b c c}+15,000 \\
{ }^{0} L_{F e: T i}^{C 14}=-85,500+410.041 T-73.553 T \ln T- \\
0.01017 T^{2}+124,212.42 T^{-1} \\
{ }^{0} L_{F e: V}^{C 14}=2{ }^{0} G_{F e}^{b c c}+{ }^{0} G_{V}^{b c c}+15,000 \\
{ }^{0} L_{T i: F e}^{C 14}=3{ }^{0} G_{T i}^{h c p}+3{ }^{0} G_{F e}^{b c c}+115,500-410.041 T+ \\
73.553 T \ln T+0.01017 T^{2}-124,212.42 T^{-1} \\
{ }^{0} L_{T i: T i}^{C 14}=3{ }^{0} G_{T i}^{h c p}+15,000 \\
{ }^{0} L_{T i V}^{C 14}=2{ }^{0} G_{T i}^{h c p}+{ }^{0} G_{V}^{b c c}+15,000 \\
{ }^{0} L_{V: F e}^{C 14}=2{ }^{0} G_{V}^{b c c}+{ }^{0} G_{F e}^{b c c}+15,000 \\
{ }^{0} L_{V: T i}^{C 14}=2{ }^{0} G_{V}^{b c c}+{ }^{0} G_{T i}^{h c p}+15,000 \\
{ }^{0} L_{V: V}^{C 14}=3{ }^{0} G_{V}^{b c c}+15,000 \\
{ }^{0} L_{F e, V: F e}^{C 14}=-133,021.5+45.5 T \\
{ }^{0} L_{F e, V: T i}^{C 14}=-82,412.5+12.5 T \\
{ }^{0} L_{F e, V: V}^{C 14}=-143,650+50 T \\
{ }^{0} L_{T i V}^{C 14}=-10,8 i=-10,830 \\
{ }^{0} L_{T i V}^{C 14}=-10,830 \\
{ }^{0} L_{V: F e, V}^{C 14}=-5000\end{array}$ & $\begin{array}{l}\text { [24] } \\
\text { This work } \\
\text { [24] } \\
\text { [24] } \\
\text { This work } \\
\text { This work } \\
\text { This work } \\
\text { This work } \\
\text { This work } \\
\text { This work } \\
\text { This work } \\
\text { This work } \\
\text { This work } \\
\text { This work }\end{array}$ \\
\hline
\end{tabular}

\subsection{Ti-Al-Fe-V System}

In view of no report on a new phase of Ti-Al-Fe-V quaternary system and the effect of the quaternary interaction parameters on the whole Gibbs energy can be ignored, the 
thermodynamic database of the Ti-Al-Fe-V quaternary system constructed by extrapolating from four ternary sub-systems using the Muggianu model [72]. For the four ternary sub-systems, as listed in Table 3, descriptions for Ti-Al-Fe [46], Ti-Al-V [56] and Al-Fe$\mathrm{V}$ [61] were already available. Although a description for the Ti-Fe-V [67] system was also available, the thermodynamic parameters of Ti-Fe and Ti-V systems were derived from Keyzer et al. [23] and Zeng et al. [25]. It can be seen from Table 3 that the thermodynamic parameters of Ti-Fe and Ti-V systems accepted from Bo et al. [24] and Ghosh et al. [27] in the present work. In order to ensure the self-consistency of thermodynamic parameters, the Ti-Fe-V system was completely re-assessed covering the whole composition range.

Table 3. Thermodynamic descriptions for constituent ternary sub-systems of the Ti-Al-Fe-V quaternary system, used in the present work.

\begin{tabular}{|c|c|c|c|c|}
\hline System & $\begin{array}{l}\text { Source of the Ternary } \\
\text { Description }\end{array}$ & $\begin{array}{c}\text { Constituent Binary } \\
\text { System }\end{array}$ & $\begin{array}{l}\text { Source of the Constituent } \\
\text { Binary Description }\end{array}$ & Postscript \\
\hline \multirow[t]{3}{*}{ Ti-Al-Fe } & Hu et al. [46] & Ti-Al & Witusiewicz et al. [18] & Adopted \\
\hline & & $\mathrm{Ti}-\mathrm{Fe}$ & Bo et al. [24] & \\
\hline & & $\mathrm{Al}-\mathrm{Fe}$ & Sundman et al. [30] & \\
\hline \multirow[t]{3}{*}{ Ti-Al-V } & Lu et al. [56] & Ti-Al & Witusiewicz et al. [18] & Adopted \\
\hline & & $\mathrm{Ti}-\mathrm{V}$ & Ghosh et al. [27] & \\
\hline & & $\mathrm{Al}-\mathrm{V}$ & Gong et al. [32] & \\
\hline \multirow[t]{3}{*}{ Al-Fe-V } & Wang et al. [61] & $\mathrm{Al}-\mathrm{Fe}$ & Sundman et al. [30] & Adopted \\
\hline & & Al-V & Gong et al. [32] & \\
\hline & & $\mathrm{Fe}-\mathrm{V}$ & Kumar et al. [35] & \\
\hline \multirow[t]{3}{*}{ Ti-Fe-V } & Present work & $\mathrm{Ti}-\mathrm{Fe}$ & Bo et al. [24] & Re-assessed in the present work \\
\hline & & $\mathrm{Ti}-\mathrm{V}$ & Ghosh et al. [27] & \\
\hline & & $\mathrm{Fe}-\mathrm{V}$ & Kumar et al. [35] & \\
\hline
\end{tabular}

The eventual purpose of the present work is to design novel titanium alloys containing $\mathrm{Al}, \mathrm{Fe}$ and $\mathrm{V}$ elements by using calculated phase diagrams, and to provide theoretical guidance for the formulation of the heat treatment process of the designed titanium alloys. The next section will illustrate in detail with examples.

\section{Alloy Design}

The most fundamental aspect of alloy design is composition design, followed by the regulation of microstructure through smelting, processing and heat treatment to obtain excellent alloy properties. The composition design of titanium alloy refers to the determination of which alloying elements and the amount to be added to the titanium matrix under certain theoretical guidance, and then the prediction of the alloy performance. At present, the main method of composition design of titanium alloy is Mo equivalent method [73]. The formulae of Mo equivalent commonly used at present are as follows [74]:

$[\mathrm{Mo}]_{\text {eq }}=1.0 \mathrm{Mo}+0.67 \mathrm{~V}+0.44 \mathrm{~W}+0.28 \mathrm{Nb}+0.22 \mathrm{Ta}+2.9 \mathrm{Fe}+1.58 \mathrm{Cr}+1.56 \mathrm{Mn}-1.0 \mathrm{Al}$

Although Mo equivalent can guide the design of different types of titanium alloys, there are also design blind spots. When Mo equivalent method is used to design titanium alloys, the content of various alloying elements still depends on the selection of experience, and the emergence of brittle phase cannot be avoided precisely, nor can it provide theoretical guidance for subsequent heat treatment process. In the present work, for the design of titanium alloys, a method combining Mo equivalent with CALPHAD is proposed. The new method can not only jointly and accurately guide the design of alloy composition, but also provide an exact theoretical basis for subsequent heat treatment of the designed alloy. Taking the Ti-Al-Fe-V quaternary system as an example, the process of designing alloys using this new method will be described in detail below.

In the development of novel titanium alloys, $\mathrm{Al}$ remains the most important and commonly used $\alpha$ stabilizer, which can suppress the formation of $\omega$ phase to a certain 
extent and promote the transformation of brittle phase $\omega$ into $\alpha$ phase [75]. Although the ultimate solubility of $\mathrm{Al}$ in $\mathrm{Ti}$ is $7.5 \mathrm{wt} \%$, when the content of $\mathrm{Al}$ exceeds $6.0 \mathrm{wt} \%$, the brittle phase $\mathrm{Ti}_{3} \mathrm{Al}$ will easily appear below $400 \mathrm{~K}$, as shown in Figure 1, therefore, the content of Al should not exceed $6.0 \mathrm{wt} \%$. Table 4 lists some titanium alloys developed in various countries [76], and the Al content of these alloys focuses in 3.0, 4.5 and $6.0 \mathrm{wt} \%$. These three $\mathrm{Al}$ contents were also selected in this work. When the Al content is fixed, the focus transfers to the ratio of the elements $\mathrm{Fe}$ and $\mathrm{V}$, and this proportion can be determined by the phase diagram of the Fe-V system, as shown in Figure 6. Based on the Fe-V phase diagram, it could be known that the sigma brittle phase and $\beta$ and sigma two-phase region existed in a wide range of components. To avoid the presence of sigma brittle phase in the designed alloy microstructure at room temperature, the selected component proportion should be $\mathrm{V}: \mathrm{Fe} \geq 7.3: 1$ or $\mathrm{V}: \mathrm{Fe} \leq 1: 3.7$. Although the cost of alloy is greatly reduced when $\mathrm{V}: \mathrm{Fe} \leq 1: 3.7$ is selected for alloy design, the brittle phase of $\mathrm{Fe}_{2} \mathrm{Ti}$ is more likely to appear with increasing Fe content, which seriously affects the mechanical properties of the alloy [77]. In addition, regardless of which heat treatment method is adopted in the subsequent heat treatment process, the temperature is always higher than the recrystallization temperature of pure titanium at $853 \mathrm{~K}\left(580^{\circ} \mathrm{C}\right)$, and the ratio of V:Fe corresponding to this temperature is 2.9:1, so the ratio of $\mathrm{V}: \mathrm{Fe}$ is optional in the range of $2.9: 1$ to $7.3: 1$, that is, the $\mathrm{S}$ part marked in Figure 6. The ratio of $\mathrm{V}: \mathrm{Fe}=3.5: 1$ is recommended to design novel titanium alloys.

Table 4. Some titanium alloys developed in various countries.

\begin{tabular}{cccc}
\hline Country & Trade Mark & Nominal Composition (wt $\%)$ & References \\
\hline USA & Timetal 62S & Ti-6Al-1.7Fe-0.1Si & {$[78]$} \\
& Timetal 21S & Ti-15Mo-2.7Nb-3Al-0.2Si & {$[80]$} \\
\multirow{2}{*}{ Japan } & Ti-1023 & Ti-10V-2Fe-3Al & {$[78]$} \\
& SP-700 & Ti-4.5Al-3V-2Mo-2Fe & {$[81]$} \\
CSTina & Ti8LC & Ti-4.5Al-2Mo-1.6V-0.5Fe-0.3Si-0.03C & {$[78]$} \\
& Ti12LC & Ti-6Al-1Fe-1Mo & {$[82]$} \\
\hline
\end{tabular}

The pseudo-binary sections are calculated based on the thermodynamic database of the Ti-Al-Fe-V system, with the ratio of $\mathrm{V}: \mathrm{Fe}=3.5: 1$ and $\mathrm{Al}$ contents of $0.0,3.0,4.5$ and $6.0 \mathrm{wt} \%$. The calculation results of these pseudo-binary sections are shown in Figures 9-12. It can be seen that with the increase in $\mathrm{Al}$ content, the solid solution area of $\alpha$ phase increases inch by inch, while the solid solution area of $\beta$ phase decreases gradually. This indicates that in the Ti-Al-Fe-V system, an Al content of $6.0 \mathrm{wt} \%$ is suitable for the design of $\alpha$ titanium alloy, and an $\mathrm{Al}$ content of $3.0 \mathrm{wt} \%$ is suitable for the design of $\beta$ titanium alloy. Between both, an $\alpha+\beta$ titanium alloy could be designed. Combined with these pseudo-binary sections, it can be seen that the brittle phase has been successfully avoided in the composition design of titanium alloys, thus the degradation of the titanium alloy properties is avoided. From Figures 9-12, it can be seen that the pseudo-binary sections can not only provide guidance for the design of titanium alloys, but also provide a theoretical basis for subsequent heat treatment process of the designed titanium alloys according to the transformation temperature of $(\alpha+\beta) / \beta$. Leyens [83] pointed out that the minimum value of Mo equivalent of approximately 10 is necessary to obtain the $\alpha+\beta$ dual phase titanium alloys during quenching, and around 30 for pure $\beta$ titanium alloys. The critical concentrations of $\mathrm{V}$ and Fe for obtaining the $\alpha, \alpha+\beta$ and $\beta$ titanium alloys are determined via the formula of Mo equivalent [74], as shown in Table 5. 


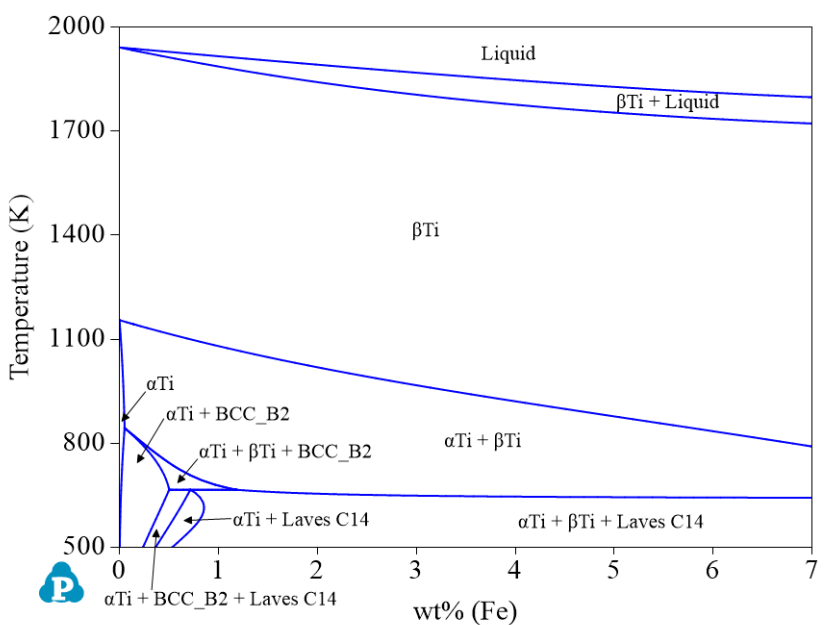

Figure 9. The calculated pseudo-binary section of $\mathrm{V}: \mathrm{Fe}=3.5: 1$ and $0.0 \mathrm{wt} \% \mathrm{Al}$.

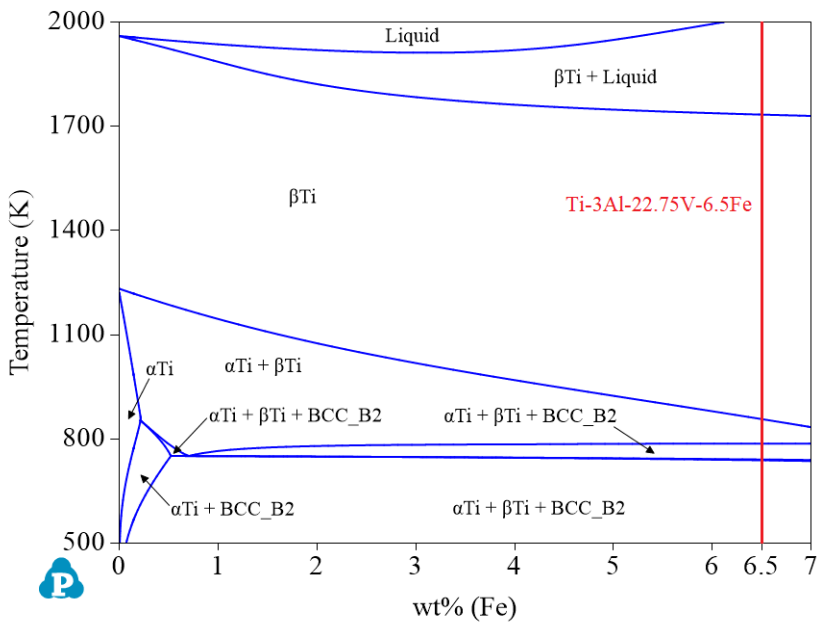

Figure 10. The calculated pseudo-binary section of $\mathrm{V}: \mathrm{Fe}=3.5: 1$ and $3.0 \mathrm{wt} \% \mathrm{Al}$.

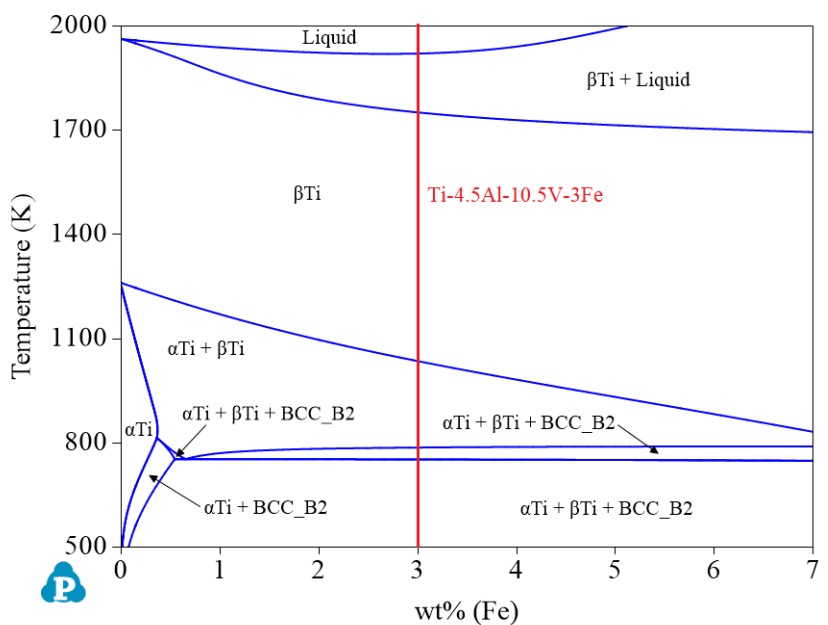

Figure 11. The calculated pseudo-binary section of $\mathrm{V}: \mathrm{Fe}=3.5: 1$ and $4.5 \mathrm{wt} \% \mathrm{Al}$. 


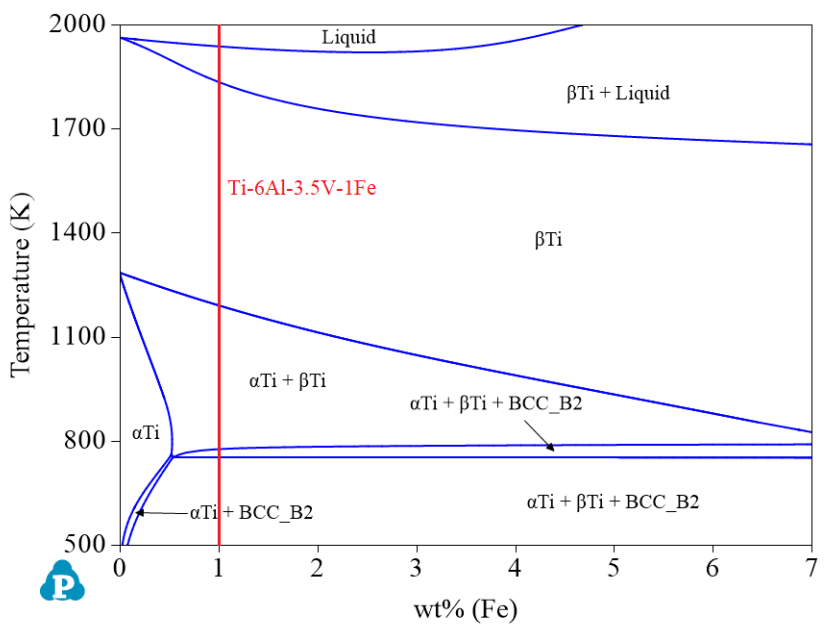

Figure 12. The calculated pseudo-binary section of $\mathrm{V}: \mathrm{Fe}=3.5: 1$ and $6.0 \mathrm{wt} \% \mathrm{Al}$.

Table 5. The critical content of the element Fe and V in different types of titanium alloys with different Al content.

\begin{tabular}{|c|c|c|c|c|c|c|}
\hline \multirow[t]{2}{*}{$\begin{array}{l}\text { The Content of } \\
\text { Al (wt } \%)\end{array}$} & \multicolumn{2}{|c|}{$\begin{array}{c}\text { The Content of Fe and V in } \alpha \\
\text { Titanium Alloys }\end{array}$} & \multicolumn{2}{|c|}{$\begin{array}{c}\text { The Content of Fe and V in } \alpha+\beta \\
\text { Titanium Alloys }\end{array}$} & \multicolumn{2}{|c|}{$\begin{array}{c}\text { The Content of Fe and } \mathrm{V} \text { in } \beta \\
\text { Titanium Alloys }\end{array}$} \\
\hline & $\mathrm{Fe}(w \mathrm{t} \%)$ & $V(w t \%)$ & $\mathrm{Fe}(w \mathrm{t} \%)$ & $V(w t \%)$ & $\mathrm{Fe}(w t \%)$ & V (wt \%) \\
\hline 3.0 & $<2.48$ & $<8.68$ & $2.48-6.29$ & $8.68-22.02$ & $>6.29$ & $>22.02$ \\
\hline 4.5 & $<2.76$ & $<9.66$ & $2.76-6.58$ & $9.66-23.03$ & $>6.58$ & $>23.03$ \\
\hline 6.0 & $<3.05$ & $<10.68$ & $3.05-6.86$ & 10.68-24.01 & $>6.86$ & $>24.01$ \\
\hline
\end{tabular}

Using the method of combining Mo equivalent with CALPHAD, three different types of novel titanium alloys are suggested below:

(1) As a strengthening element of the $\alpha$ phase, the $\alpha$ single-phase region of a keeps expanding with increasing $\mathrm{Al}$ content. Figure 12 shows that when the $\mathrm{Al}$ content is $6.0 \mathrm{wt} \%$, the largest $\alpha$ single-phase region is observed. Therefore, if you want to design $\alpha$ titanium alloys of the Ti-Al-Fe-V system, $6.0 \mathrm{wt} \% \mathrm{Al}$ can be preferred. At this time, the ranges of $\mathrm{Fe}$ and $\mathrm{V}$ are $0-3.05 \mathrm{wt} \%$ and $0-10.68 \mathrm{wt} \%$, respectively. The recommended alloy composition is Ti-6Al-3.5V-1Fe, and its actual Mo equivalent is -0.755 , which is considered to be 0 .

(2) $\mathrm{V}$ and $\mathrm{Fe}$, as $\beta$ phase reinforcing elements, can enlarge the $\beta$ phase region. To obtain $\beta$ titanium alloy, the content of elements $V$ and Fe should be within the appropriate range as much as possible. Figure 10 shows that when the $\mathrm{Al}$ content is $3.0 \mathrm{wt} \%$, the largest $\beta$ single-phase region is observed. Therefore, if you want to design $\beta$ titanium alloys of the Ti-Al-Fe-V system, $3.0 \mathrm{wt} \% \mathrm{Al}$ can be preferred. At this time, the ranges of Fe and $\mathrm{V}$ are greater than $6.29 \mathrm{wt} \%$ and $22.02 \mathrm{wt} \%$, respectively. The recommended alloy composition is Ti-3Al-22.75V-6.5Fe, and its Mo equivalent is 31 .

(3) Although $\alpha$ titanium alloys and $\beta$ titanium alloys can also be designed when the $\mathrm{Al}$ content is $4.5 \mathrm{wt} \%$, the range of options did not reach the optimal when compared with the other two concentrations. Therefore, when the $\mathrm{Al}$ content is $4.5 \mathrm{wt} \%$, as shown in Figure 11, priority should be given to design $\alpha+\beta$ titanium alloys. At this time, the ranges of $\mathrm{Fe}$ and $\mathrm{V}$ are $2.76-6.58 \mathrm{wt} \%$ and $9.66-23.03 \mathrm{wt} \%$, respectively. The recommended alloy composition is Ti-4.5Al-10.5V-3Fe, and its Mo equivalent is 11.2.

Figures 10-12 are thermodynamic equilibrium phase diagram, from which it can be seen that the designed $\alpha, \alpha+\beta$ and $\beta$ titanium alloys cannot be obtained at room temperature. However, due to the factors of alloy diffusion kinetics, the designed $\alpha, \alpha+\beta$ and $\beta$ titanium alloys can be obtained at room temperature by adopting appropriate heat 
treatment process. Three types of titanium alloys have been successfully designed by the method and the properties of these alloys need to be further studied.

\section{Conclusions}

In the present work, the experimental investigation and thermodynamic description of the relative sub-systems of the Ti-Al-Fe-V quaternary system were summarized and reviewed. The Ti-Fe-V system was re-assessment based on critical review of experimental data, and the calculated results were in satisfactory agreement with the reported experimental data. The thermodynamic database of the Ti-Al-Fe-V quaternary system was subsequently established by extrapolating the thermodynamic descriptions of the accepted sub-binary and sub-ternary systems. Then, the method of titanium alloy design combining Mo equivalent with CALPHAD was proposed. The pseudo-binary sections with $\mathrm{V}: \mathrm{Fe}=3.5: 1$ and $\mathrm{Al}=0.0,3.0,4.5$ and $6.0 \mathrm{wt} \%$ were calculated. Finally, three different types of titanium alloys were recommended according to the proposed method: $\alpha$ titanium alloy (Ti-6Al-3.5V-1Fe), $\beta$ titanium alloy (Ti-3Al-22.75V-6.5Fe) and $\alpha+\beta$ titanium alloy (Ti-4.5Al-10.5V-3Fe). The thermodynamic database established and the method proposed in the present work are expected to guide future development of titanium alloys containing $\mathrm{Al}, \mathrm{Fe}$ and $\mathrm{V}$.

Author Contributions: Conceptualization, X.L.; methodology, C.L.; software, Q.F. and B.D.; validation, C.L.; formal analysis, Q.F. and L.J.; investigation, Q.F.; resources, L.M. and L.J.; data curation, B.D. and L.M.; writing-original draft preparation, Q.F.; writing-review and editing, G.C. and C.L.; visualization, Q.F.; supervision, G.C. and C.L.; project administration, Q.F. and G.C.; funding acquisition, C.L. All authors have read and agreed to the published version of the manuscript.

Funding: This research was funded by National Natural Science Foundation of China (Contract: U1860203; 52022054; 51974181; 52104305), the Shanghai Rising-Star Program (19QA1403600), and the Program for Professor of Special Appointment (Eastern Scholar) at Shanghai Institutions of Higher Learning (TP2019041).

Institutional Review Board Statement: Not applicable.

Informed Consent Statement: Not applicable.

Data Availability Statement: Available upon request.

Acknowledgments: We would like to thank Xingli Zou for his language support. We would also like to thank the anonymous reviewers for their constructive comments on this paper.

Conflicts of Interest: The authors declare no conflict of interest.

\section{References}

1. Lu, K. The future of metals. Science 2010, 328, 319-320. [CrossRef] [PubMed]

2. Boyer, R.R. Attributes, characteristics, and applications of titanium and its alloys. JOM 2017, 3, 15-18. [CrossRef]

3. Qiu, C.; Fones, A.; Hamilton, H.G.C.; Adkins, N.J.E.; Attallah, M.M. A new approach to develop palladium-modified Ti-based alloys for biomedical applications. Mater. Des. 2016, 109, 98-111. [CrossRef]

4. He, P.Z.; Huang, S.M.; Guo, W.; Wang, Y.F.; He, L. The present situation of the word sponge titanium industry and the reflection on the future development of China. Prog. Titan. Ind. 2017, 34, 1-4.

5. Gazder, A.A.; Vu, V.Q.; Saleh, A.A.; Markovsky, P.E.; Ivasishin, O.M.; Davies, C.H.J.; Pereloma, E.V. Recrystallisation in a cold drawn low cost beta titanium alloy during rapid resistance heating. J. Alloys Compd. 2014, 585, 245-259. [CrossRef]

6. Zadra, M.; Girardini, L. High-performance, low-cost titanium metal matrix composites. Mater. Sci. Eng. A 2014, 608, 155-163. [CrossRef]

7. Santos, P.F.; Niinomi, M.; Cho, K.; Nakai, M.; Liu, H.; Ohtsu, N.; Hirano, M.; Ikeda, M.; Narushima, T. Microstructures, mechanical properties and cytotoxicity of low cost beta Ti-Mn alloys for biomedical applications. Acta Biomater. 2015, 26, 366-376. [CrossRef]

8. Bodunrin, M.O.; Chown, L.N.; Omotoyinbo, J.A. Development of low-cost titanium alloys: A chronicle of challenges and opportunities. Mater. Today Proc. 2021, 38, 5-7. [CrossRef]

9. Robertson, I.M.; Schaffer, G.B. Review of densification of titanium based powder systems in press and sinter processing. Powder Metall. 2010, 53, 146-162. [CrossRef]

10. Bryan, D. ATI $425^{\circledR}$ Alloy Formability: Theory and Application. Mater. Sci. Forum 2014, 783-786, 543-548. [CrossRef] 
11. Zhang, C.; Yin, H.; Zhang, R.; Jiang, X.; Liu, G.; Du, Y. Experimental and thermodynamic investigation of gradient zone formation for $\mathrm{Ti}(\mathrm{C}, \mathrm{N})$-based cermets sintered in nitrogen atmosphere. Ceram. Int. 2017, 43, 12089-12094. [CrossRef]

12. Kattner, U.R.; Lin, J.C.; Chang, Y.A. Thermodynamic assessment and calculation of the Ti-Al system. Metall. Mater. Trans. A 1992, 23, 2081-2090. [CrossRef]

13. Okamoto, H. Al-Ti (aluminum-titanium). J. Phase Equilib. 1993, 14, 764. [CrossRef]

14. Zhang, F.; Chen, S.L.; Chang, Y.A.; Kattner, U.R. A thermodynamic description of the Ti-Al system. Intermetallics 1997, 5, 471-482. [CrossRef]

15. Braun, J.; Ellner, M. Phase equilibria investigations on the aluminum-rich part of the binary system Ti-Al. Metall. Mater. Trans. A 2001, 32, 1037-1047. [CrossRef]

16. Ohnuma, I.; Fujita, Y.; Mitsui, H.; Ishikawa, K.; Kainuma, R.; Ishida, K. Phase equilibria in the Ti-Al binary system. Acta Mater. 2000, 48, 3113-3123. [CrossRef]

17. Kostov, A.; Friedrich, B.; Zivkovic, D. Thermodynamic calculations in alloys Ti-Al, Ti-Fe, Al-Fe and Ti-Al-Fe. J. Min. Metall. Sect. B 2008, 44, 49-61. [CrossRef]

18. Witusiewicz, V.T.; Bondar, A.A.; Hecht, U.; Rex, S.; Velikanova, T.Y. The Al-B-Nb-Ti system III: Thermodynamic re-evaluation of the constituent binary system Al-Ti. J. Alloys Compd. 2008, 465, 64-77. [CrossRef]

19. Ohtani, H.; Hillert, M. A thermodynamic assessment of the Fe-N-Ti system. Calphad 1991, 15, 41-52. [CrossRef]

20. Kumar, K.C.H.; Wollaiits, P.; Delaey, L. Thermodynamic reassessment and calculation of Fe-Ti phase diagram. Calphad 1994, 18, 223-234. [CrossRef]

21. Dumitrescu, L.F.S.; Hillert, M.; Saunders, N. Comparison of Fe-Ti assessments. J. Phase Equilib. 1998, 19, 441-448. [CrossRef]

22. Jonsson, S. Assessment of the Fe-Ti system. Metall. Mater. Trans. B 1998, 29, 361-370. [CrossRef]

23. Keyzer, J.D.; Cacciamani, G.; Dupin, N.; Wollants, P. Thermodynamic modeling and optimization of the Fe-Ni-Ti system. Calphad 2009, 33, 109-123. [CrossRef]

24. Bo, H.; Wang, J.; Duarte, L.; Leinenbach, C.; Liu, L.B.; Liu, H.S.; Jin, Z.P. Thermodynamic re-assessment of Fe-Ti binary system. Trans. Nonferr. Met. Soc. China 2012, 22, 2204-2211. [CrossRef]

25. Zeng, K.; Schmid-Fetzer, R. Thermodynamic assessment and applications of Ti-V-N system. Mater. Sci. Technol. 1998, 14, 1083-1091. [CrossRef]

26. Lindwall, G.; Wang, P.; Kattner, U.R.; Campbell, C.E. The effect of oxygen on phase equilibria in the Ti-V system: Impacts on the AM processing of Ti alloys. JOM 2018, 70, 1692-1705. [CrossRef]

27. Ghosh, G. Thermodynamic and kinetic modeling of the Cr-Ti-V system. J. Phase Equilib. 2002, 23, 310-328. [CrossRef]

28. Jacobs, M.H.G.; Schmid-Fetzer, R. Phase behavior and thermodynamic properties in the system Fe-Al. Calphad 2009, 33, 170-178. [CrossRef]

29. Phan, A.T.; Paek, M.K.; Kang, Y.B. Phase equilibria and thermodynamics of the Fe-Al-C system: Critical evaluation, experiment and thermodynamic optimization. Acta Mater. 2014, 79, 1-15. [CrossRef]

30. Sundman, B.; Ohnuma, I.; Dupin, N.; Kattner, U.R.; Fries, S.G. An assessment of the entire Al-Fe system including D0 3 ordering. Acta Mater. 2009, 57, 2896-2908. [CrossRef]

31. Kroupa, A.; Mazalova, M.; Richter, K.W. The reassessment of the Al-V system and new assessment of the Al-Si-V system. Calphad 2017, 59, 47-60. [CrossRef]

32. Gong, W.P.; Du, Y.; Huang, B.Y.; Schmid-Fetzer, R.; Zhang, C.F.; Xu, H.H. Thermodynamic reassessment of the Al-V system. Z. Met. 2004, 95, 978-986. [CrossRef]

33. Lee, B.J.; Lee, D.N. A thermodynamic study on the V-C and Fe-V systems. Calphad 1991, 15, $283-291$.

34. Andersson, J.O. A thermodynamic evaluation of the iron-vanadium system. Calphad 1983, 7, 305-315. [CrossRef]

35. Kumar, K.C.H.; Raghavan, V. A thermodynamic reassessment of the Fe-V system. Calphad 1991, 15, 307-314. [CrossRef]

36. Zeng, L.J.; Xu, G.L.; Liu, L.B.; Bai, W.M.; Zhang, L.G. Experimental investigation of phase equilibria in the Ti-Fe-Zr system. Calphad 2018, 61, 20-32. [CrossRef]

37. Hu, B.; Yao, B.; Wang, J.; Zhao, J.R.; Min, F.F.; Du, Y. Thermodynamic assessment of the Al-Mo-V ternary system. J. Min. Metall. Sect. B 2017, 53, 95-106. [CrossRef]

38. Zhao, C.C.; Yang, S.Y.; Lu, Y.; Guo, Y.H.; Wang, C.P.; Liu, X.J. Experimental investigation and thermodynamic calculation of the phase equilibria in the Fe-Ni-V system. Calphad 2014, 46, 80-86. [CrossRef]

39. Palm, M.; Inden, G.; Thomas, N. The Fe-Al-Ti system. J. Phase Equilib. 1995, 16, 209-222. [CrossRef]

40. Mabuchi, H.; Nagayama, H.; Tsuda, H.; Matsui, T.; Morii, K. Formation of ternary L1_2 intermetallic compound and phase relation in the Al-Ti-Fe system. Mater. Trans. JIM 2000, 41, 733-738. [CrossRef]

41. Kainuma, R.; Ohnuma, I.; Ishikawa, K.; Ishida, K. Stability of $\mathrm{B}_{2}$ ordered phase in the Ti-rich portion of Ti-Al-Cr and Ti-Al-Fe ternary systems. Intermetallics 2000, 8, 869-875. [CrossRef]

42. Ducher, R.; Stein, F.; Viguier, B.; Palm, M.; Lacaze, J. A re-examination of the liquidus surface of the Al-Fe-Ti system. Z. Met. 2003, 94, 396-410. [CrossRef]

43. Palm, M.; Lacaze, J. Assessment of the Al-Fe-Ti system. Intermetallics 2006, 14, 1291-1303. [CrossRef]

44. Takahashi, T.; Minamino, Y. Ternary diffusion and thermodynamic interaction in the beta solid solutions of Ti-Al-Fe alloys at 1423 K. J. Alloys Compd. 2012, 545, 168-175. [CrossRef] 
45. Rafiei, M.; Enayati, M.H.; Karimzadeh, F. Thermodynamic analysis of solid solution formation in the nanocrystalline Fe-Ti-Al ternary system during mechanical alloying. J. Chem. Thermodyn. 2013, 59, 243-249. [CrossRef]

46. Hu, R.M. Thermodynamic Evaluation of Ti-Al-Fe-Mn Quaternary System and Its Application in the Design of Novel Titanium Alloys. Master's Thesis, Shanghai University, Shanghai, China, 2015.

47. Hayes, F.H. The Al-Ti-V (aluminum-titanium-vanadium) system. J. Phase Equilib. 1995, 16, 163-176. [CrossRef]

48. Farrar, P.A.; Margolin, H. The Titanium-rich region of the Titanium-Aluminum-Vanadium system. Trans. Am. Inst. Min. Metall. Pet. Eng. 1961, 221, 1214-1221.

49. Ahmed, T.; Flower, H. Partial isothermal sections of Ti-Al-V ternary diagram. Mater. Sci. Technol. 1994, 10, 272-288. [CrossRef]

50. Shao, G.; Miodownik, A.P.; Tsakiropoulos, P. w-Phase formation in V-Al and Ti-Al-V alloys. Philos. Mag. A 1995, 71, 1389-1408. [CrossRef]

51. Shao, G.; Tsakiropoulos, P.; Miodownik, A.P. Ordering and decomposition of the $\beta$ phase in melt-spun TiAl $\mathrm{I}_{1-\mathrm{x}} \mathrm{V}_{\mathrm{x}}$ alloys. Mater Sci. Eng. A 1996, 216, 1-10. [CrossRef]

52. Chang, W.S.; Muddle, B.C. Structure and stability of a new ternary hexagonal phase in $\mathrm{Al}_{3}$ Ti-based Al-Ti-V alloys. Metall. Mater Trans. A 2003, 34, 491-501. [CrossRef]

53. Zhang, Y.Q.; Du, Y. $1100{ }^{\circ} \mathrm{C}$ isothermal section of Ti-Al-V ternary system. Mater. Sci. Eng. Powder Metall. 2006, 11, 146-148. [CrossRef]

54. Kostov, A.; Zivkovic, D. Thermodynamic analysis of alloys Ti-Al, Ti-V., Al-V and Ti-Al-V. J. Alloys Compd. 2008, 460, 164-171. [CrossRef]

55. Wang, H.; Warnken, N.; Reed, R.C. Thermodynamic and kinetic modeling of bcc phase in the Ti-Al-V ternary system. Mater. Sci. Eng. A 2010, 528, 622-630. [CrossRef]

56. Lu, X.G.; Gui, N.; Qiu, A.T.; Wu, G.X.; Li, C.H. Thermodynamic Modeling of the Al-Ti-V Ternary System. Metall. Mater. Trans. A 2014, 45, 4155-4164. [CrossRef]

57. Miyazaki, T.; Kozakai, T. Experimental and theoretical investigations on phase diagram of Fe-base ternary ordering alloys. $J$. Chim. Phys. Chim. Biol. 1997, 94, 844-848. [CrossRef]

58. Schoo, K.L.; Sivaramakrishnan, C.S.; Chakrabarti, A.K. Solidification characteristics of the Al-8.3Fe-0.8V-0.9Si alloy. Metall. Mater Trans. A 2000, 31, 1599-1610. [CrossRef]

59. Zhao, P.Z.; Kozakai, T.; Miyazaki, T. Phase separations into A2 + $\mathrm{DO}_{3}$ two phases in Fe-Al-V ternary ordering alloys. J. Jpn. Inst. Met. Mater. 1989, 53, 266-272. [CrossRef]

60. Maebashi, T.; Kozakai, T.; Doi, M. Phase equilibria in iron-rich Fe-Al-V ternary alloy system. Z. Met. 2004, 95, 1005-1010. [CrossRef]

61. Wang, J.; Feng, Q.S.; Wang, S.H.; Lu, X.G.; Li, C.H. Thermodynamic modeling of Al-Fe-V ternary system. Mater. Res. Express 2019, 6, 126539. [CrossRef]

62. Tsin-Khua, B.; Kornilov, I.I. Fe-V-Ti (iron-vanadium-Titanium). J. Inorg. Chem. 1960, 5, 434. (In Russian)

63. Ghosh, G.; Raghavan, V. Progress in metallurgical research: Fundamental and applied aspects. In Proceedings of the International Conference, Indian Institute of Technology, Kampur, India, 11 February 1986; pp. 403-408.

64. Villars, P.; Prince, A.; Okamoto, H. Handbook of Ternary Alloy Phase Diagrams; ASM International: Cleveland, OH, USA, 1995; Volume 7, pp. 10927-10934.

65. Prima, S.B.; Tretyachenko, L.A. Area of homogeneity of Laves phase in the Ti-V-Fe ternary system. Sov. Powder Metall. Met. Ceram. 1987, 26, 414-415. [CrossRef]

66. Massicot, B.; Joubert, J.M.; Latroche, M. Phase equilibria in the Fe-Ti-V system. Int. J. Mater. Res. 2010, 101, 1414-1423. [CrossRef]

67. Guo, G.P.; Li, C.R.; Zheng, X.; Du, Z.M. Thermodynamic modeling of the Fe-Ti-V system. Calphad 2012, 38, 155-160. [CrossRef]

68. Dinsdale, A.T. SGTE data for pure elements. Calphad 1991, 15, 317-425. [CrossRef]

69. Redlich, O.; Kister, A.T. Algebraic representation of thermodynamic properties and the classification of solutions. Ind. Eng. Chem. 1948, 40, 345-348. [CrossRef]

70. Available online: https://computherm.com/ (accessed on 16 November 2021).

71. Wang, S.S.; Wang, K.; Chen, G.Y.; Li, Z.; Qin, Z.W.; Lu, X.G.; Li, C.H. Thermodynamic modeling of Ti-Fe-Cr ternary system. Calphad 2017, 56, 160-168. [CrossRef]

72. Muggianu, Y.M.; Bambino, M.; Bros, J.P. Enthalpy of formation of liquid Bi-Sn-Ga alloys at $723 \mathrm{~K}$, choice of an analytical expression of integral and partial excess quantities of mixing. J. Chim. Phys. 1975, 72, 83-88. [CrossRef]

73. Kolachev, B.; Il'in, A.A.; Ryndenkov, D. Structural diagrams of titanium alloys in the "molybdenum equivalent-aluminum equivalent" coordinates. Russ. Metall. 1997, 1, 118-128.

74. Wang, H.B.; Wang, S.S.; Gao, P.Y.; Jiang, T.; Lu, X.G.; Li, C.H. Microstructure and mechanical properties of a novel near- $\alpha$ titanium alloy Ti6.0Al4.5Cr1.5Mn. Mater. Sci. Eng. A 2016, 672, 170-174. [CrossRef]

75. Li, C.L.; Lee, D.; Mi, X.J.; Ye, W.J.; Hui, S.X.; Lee, Y.T. Effect of Al addition on $\omega$ precipitation and age hardening of Ti-Al-Mo-Fe alloys. Metall. Mater. Trans. A 2016, 47, 2454-2461. [CrossRef]

76. Feng, Q.Y.; Tong, X.W.; Wang, J.; Wang, D.C.; Gao, Q. Status quo and development tendency on the research of low-cost titanium alloy. Mater. Rev. 2017, 31, 128-134.

77. Zhao, Y.Q.; Liu, J.L.; Zhou, L. Segregation law of Cu, Fe and Cr in typical titanium alloy. Rare Met. Mater. Eng. 2005, 34, 531-538. 
78. Shang, G.Q.; Wang, X.N.; Fei, Y.; Li, J.; Zhu, Z.S.; Zhu, L.W. Experimental study on heat yreatment processing of a new low cost titanium alloy used in aviation field. Mater. Sci. Forum 2013, 747-748, 919-925. [CrossRef]

79. Reynolds, A.P.; Hood, E.; Tang, W. Texture in friction stir welds of Timetal 21S. Scr. Mater. 2005, 52, 491-494. [CrossRef]

80. Srinivasu, G.; Natraj, Y.; Bhattacharjee, A.; Nandy, T.K.; Nageswara Rao, G.V.S. Tensile and fracture toughness of high strength $\beta$ Titanium alloy, Ti-10V-2Fe-3Al, as a function of rolling and solution treatment temperatures. Mater. Des. 2013, 47, 323-330. [CrossRef]

81. Akahori, T.; Niinomi, M.; Nakai, M.; Tsutsumi, H.; Aki, S.; Itsumi, Y.; Murakami, S.; Oyama, H. Relationship between microstructures and mechanical properties in Ti-4.5Al-2Mo-1.6V-0.5Fe-0.3Si-0.03C for next-generation aircraft applications. Mater. Trans. 2013, 54, 783-790. [CrossRef]

82. Wang, Z.G.; Cai, H.J.; Hui, S.X. Microstructure and mechanical properties of a novel Ti-Al-Cr-Fe titanium alloy after solution treatment. J. Alloys Compd. 2015, 640, 253-259. [CrossRef]

83. Leyens, C.; Peters, M. Titanium and Titanium Alloys: Fundamentals and Applications; WILEY-VCH Verlag GmbH \& Co.: Weinheim, Germany, 2003. 